\title{
Reducing capacity and enzyme activity of chromate reductase in a ChrT-engineered strain
}

\author{
SIMIN ZHOU ${ }^{*}$, LANLAN DONG $^{1 *}$, PENG DENG $^{2}$, YAN JIA $^{1}$, QUNHUA BAI $^{1}$, JIEYING GAO $^{1}$ and HONG XIAO ${ }^{1}$ \\ ${ }^{1}$ Department of Health Laboratory Technology, School of Public Health and Management, Research Center for Medicine \\ and Social Development, Innovation Center for Social Risk Governance in Health, Chongqing Medical University, \\ Chongqing 400016; ${ }^{2}$ Yubei District Center for Disease Control and Prevention, Chongqing 401120, P.R. China
}

Received June 14, 2016; Accepted April 28, 2017

DOI: $10.3892 /$ etm.2017.4775

\begin{abstract}
In order to remediate the metal-contaminated soil and water ecosystems with microorganisms, an engineered strain, which contained the chromate reductase ChrT gene from Serratia sp. S2, was studied in detail for its Cr (VI) reduction efficiency, optimal culture condition and chromate reductase activity. Results demonstrated that the engineered strain had a high $\mathrm{Cr}$ (VI) reduction rate of up to $40 \%$ at a concentration of $50 \mathrm{mg} / \mathrm{l}$ after being cultured for $48 \mathrm{~h}$. Additionally, the optimal culture conditions were $\mathrm{pH} 7.0$ and $37^{\circ} \mathrm{C}$. Furthermore, the carbon sources and metal cations exhibited significant effects on the $\mathrm{Cr}$ (VI) reduction rate of the engineered bacterium. Sodium lactate, sodium acetate, $\mathrm{Cu}^{2+}, \mathrm{Co}^{2+}$ and $\mathrm{Pb}^{2+}$ were positively correlated with the reduction rate. Chromate reductase was soluble and presented in the cytoplasm. Furthermore, the enzymatic activity with nicotinamide adenine dinucleotide phosphate, which was as an electron donor, reached $14.83 \mathrm{U} / \mathrm{mg}$.
\end{abstract}

\section{Introduction}

Chromium is widely used in metallurgy, tanning, pigments, dyes, perfumes, coinage, pharmaceuticals and other industries, and thus has huge economic value despite its role as one of the main heavy metal-inducing environmental pollutants with great toxicity (1). The stable state of chromium in the environment is $\mathrm{Cr}$ (VI) and $\mathrm{Cr}$ (III). Cr (VI) has characteristics of extreme toxicity, carcinogenicity, teratogenicity and mutagenicity $(2,3)$

Correspondence to: Dr Hong Xiao, Department of Health Laboratory Technology, School of Public Health and Management, Research Center for Medicine and Social Development, Innovation Center for Social Risk Governance in Health, Chongqing Medical University, 1 Yixueyuan Road, Chongqing 400016, P.R. China

E-mail: xhk20@sina.com

*Contributed equally

Key words: engineered bacteria, hexavalent chromium, chromate reductase whereas $\mathrm{Cr}$ (III) is less toxic and relatively stable in the environment (4). Therefore, a reduction of $\mathrm{Cr}$ (VI) to $\mathrm{Cr}$ (III) can be used to govern chromium contamination. At present, the most commonly used methods for controlling chromium pollution include physical, chemical, biological and other methods, in which physical chemistry methods have a high cost and typically cause secondary pollution (5). Since bioremediation technology has characteristics of multiple processing forms, is a relative simple operation, causes a small perturbation to the environment and no destruction of soil for plant growth, it is increasingly attracting the attention of researchers (6). To date, various bacteria that are capable of reducing $\mathrm{Cr}$ (VI) have been isolated, including Arthrobacter (7), Bacillus (8), Microbacterium (9), Brucella (10) and Pseudomonas (11). In fact, the majority of studies on microorganisms are focused on isolating and culturing wild strains from environments contaminated with chromium (12), while few studies have focused on the associated genes and proteins to reduce chromium (13).

The ChrT gene that is capable of producing chromium reductase was reported in the Serratia spp. S2 strain (14), and ChrT-engineered bacteria were successfully constructed by applying genetic engineering technology (15). In the present study, the reduction capacity of ChrT-engineered bacteria was validated and culture conditions that can influence the reduction efficiency of $\mathrm{Cr}$ (VI) were associated. Furthermore, the enzyme activity of ChrT was also detected. The results of the present study may provide a basis and reference for controlling chromium pollution via microbial methods.

\section{Materials and methods}

Bacterial culturing. ChrT-engineered bacteria created in our previous study (16) were recovered from the $-80^{\circ} \mathrm{C}$ freezer and cultured in Luria-Bertani (LB) liquid medium (Sangon Biotech Co., Ltd., Shanghai, China) at $37^{\circ} \mathrm{C}$ with vibration overnight. When the absorbance value of A600 reached 2.0, the suspension medium was removed for identification by polymerase chain reaction (PCR) analysis. The ChrT gene was amplified using 2xPfu PCR MasterMix (Tiangen Biotech Co., Ltd., Beijing, China). The thermocycling conditions used were as follows: $94^{\circ} \mathrm{C}$ for $3 \mathrm{~min}$ followed by 30 cycles at $94^{\circ} \mathrm{C}$ for $30 \mathrm{sec}, 56^{\circ} \mathrm{C}$ for $30 \mathrm{sec}$ and $72^{\circ} \mathrm{C}$ for $1 \mathrm{~min}$, and 1 cycle at $72^{\circ} \mathrm{C}$ 
for $5 \mathrm{~min}$. The primer sequences were ChrT, forward 5'-ATC ATGTCAGATACCTTGAAAGTGG-3' and reverse ChrT 5'-TGCTTTAACCCGCCGAATATA-3' (Sangon Biotech Co., Ltd., Shanghai, China). Serratia sp. S2 and Escherichia coli BL21 (DE3) were also cultured in LB medium at $37^{\circ} \mathrm{C}$ with vibration overnight.

Comparison of the capability of reducing $\mathrm{Cr}$ (VI) among different bacteria. Cultured ChrT-engineered bacteria [E. coli B21 (DE3) + ChrT recombinant plasmid], Serratia spp. S2 and E. coli BL21 (DE3) were seeded into LB liquid medium containing $50 \mathrm{mg} / \mathrm{l} \mathrm{Cr}$ (VI; Hong Sheng Chemical Co., Ltd., Jiande, China) and cultured at $37^{\circ} \mathrm{C}$ with vibration. Furthermore, timing sampling and the diphenyl hydrazine spectrophotometric method (17) was used to detect the $\mathrm{Cr}$ (VI) concentration in the medium. The blank control was performed in medium without bacteria. Each sample was repeated thrice.

Effects of culture conditions on the reduction capacity to $\mathrm{Cr}$ (VI) by ChrT-engineered bacteria. A total of $10^{9}$ ChrT-engineered bacteria were seeded into LB liquid medium containing $50 \mathrm{mg} / \mathrm{l} \mathrm{Cr}(\mathrm{VI})$ at different $\mathrm{pH}$ values ( $\mathrm{pH}$ 5.0-11.0) with vibration culturing at $37^{\circ} \mathrm{C}$. Following culturing for $48 \mathrm{~h}$, the concentration of $\mathrm{Cr}(\mathrm{VI})$ was detected to determine the optimal $\mathrm{pH}$. Each treatment was repeated thrice. Under an optimal $\mathrm{pH}$, the ChrT-engineered bacteria were also cultured at different temperatures $\left(20,25,30,37,40\right.$ and $\left.50^{\circ} \mathrm{C}\right)$. After $48 \mathrm{~h}$, the $\mathrm{Cr}$ (VI) concentration was detected to select the optimal culturing temperature.

The LB liquid medium containing $1 \mathrm{~g} / 1 \mathrm{starch}$, sucrose, glucose, methanol, ethanol, sodium citrate, sodium acetate and sodium lactate was used to culture the ChrT-engineered bacteria. Under the optimal $\mathrm{pH}$ and temperature, the $\mathrm{Cr}$ (VI) concentration was detected after culturing for $48 \mathrm{~h}$. Next, the influence of a carbon source on reducing the capability of $\mathrm{Cr}(\mathrm{VI})$ was determined.

In order to estimate the effect of different metal ions on the reductase capacity of $\mathrm{Cr}(\mathrm{VI}), \mathrm{LB}$ liquid medium containing different ions was used to culture the ChrT-engineered bacteria. A total of $1 \mathrm{~mol} / 1 \mathrm{Ca}^{2+}, \mathrm{K}^{+}, \mathrm{Co}^{2+}, \mathrm{Mn}^{2+}, \mathrm{Zn}^{+}, \mathrm{Mg}^{2+}$, $\mathrm{Cu}^{2+}, \mathrm{Fe}^{3+}$ and $\mathrm{Pb}^{2+}$ (Hong Sheng Chemical Co., Ltd.) was added into the medium. After vibration culturing for $48 \mathrm{~h}$, the $\mathrm{Cr}$ (VI) concentration was detected.

Positioning and enzymatic activity of chromium-reductase ChrT. Atotal of $10^{9} \mathrm{ChrT}$-engineered bacteria were cultured in LB liquid medium containing Kana (Sangon Biotech Co., Ltd.) at $37^{\circ} \mathrm{C}$ and vibration at $150 \mathrm{rpm}$. Following induction with isopropyl $\beta$-D-1-thiogalactopyranoside (IPTG; Sangon Biotech Co., Ltd.), the outer periphery, soluble intracellular content and inclusion bodies were extracted for 15\% SDS-PAGE analysis. Next, the expressing position and solubility of the target protein was determined, as previously described (16).

Following IPTG induction, the engineered bacteria were lysed by sonication and centrifuged at $6,000 \mathrm{x} \mathrm{g}$ at $4^{\circ} \mathrm{C}$ for $40 \mathrm{~min}$ in order to obtain the supernatant. An enzymatic reaction system of $1 \mathrm{ml}$ [including $2.5 \mathrm{mmol} / 1$ nicotinamide adenine dinucleotide phosphate (NADPH; $0.2 \mathrm{ml}$ ), $25 \mathrm{mg} / 1$ $\mathrm{Cr}(\mathrm{VI} ; 0.1 \mathrm{ml})$, enzyme solution $(0.3 \mathrm{ml})$ and $0.4 \mathrm{ml}(\mathrm{pH} 8.0)$
PBS buffer] was established at $37^{\circ} \mathrm{C}$. After $30 \mathrm{~min}$, the $\mathrm{Cr}$ (VI) concentration was detected in the system. The blank control group had the same reaction system without NADPH. By comparing the $\mathrm{Cr}$ (VI) content in different groups, the reductase capacity of chromium reductase ChrT was evaluated. Additionally, enzymatic activity was calculated in the experimental group. Activity defined as 1 unit was the amount of enzyme required to convert $1 \mathrm{nmol} \mathrm{Cr}$ (VI) of substrate in $30 \mathrm{~min}$ at $37^{\circ} \mathrm{C}$.

Statistical analysis. All data were input into Microsoft Excel (Microsoft Corp., Redmond, WA, USA) and analyzed using SPSS 19.0 software (IBM Corp, Armonk, NY, USA). Variance analysis was used to compare the mean among different groups, and the Student-Newman-Keuls test was used for pairwise comparisons among multiple samples. $\mathrm{P}<0.05$ was considered to indicate a statistically significant difference.

\section{Results}

ChrT-engineered bacteria identification by PCR. In order to validate that the engineered bacteria still contain the ChrT gene, PCR was used to amplify the ChrT sequence. Genomic DNA of the engineered bacteria was used as a template with the primers (12). It was shown by agarose gel electrophoresis that the length of the PCR amplified product was $\sim 600 \mathrm{bp}$, which was approximately the same size as the sequence of chromium reductase ChrT (567 bp), as shown in Fig. 1. The results indicated that the ChrT gene was successfully cloned into the genome of the bacteria.

Comparison of the capability to eliminate Cr (VI) among different strains. To evaluate the capability of eliminating $\mathrm{Cr}$ (VI) among ChrT-engineered bacteria, Serratia spp. S2 and E. coli BL21 (DE3), the concentration of $\mathrm{Cr}$ (VI) in the medium of different bacteria was detected. As shown in Fig. 2, the capability of eliminating Cr (VI) in Serratia spp. S2 was the strongest among the three strains; the Cr (VI) concentration was significantly lower than other strains at 4 , 8,12 and $24 \mathrm{~h}(\mathrm{P}<0.05)$. Furthermore, at $48 \mathrm{~h}$, the $\mathrm{Cr}(\mathrm{VI})$ concentration was decreased to $\sim 20 \mathrm{mg} / \mathrm{l}$, which was not significantly different to that in ChrT-engineered bacteria $(\mathrm{P}>0.05)$. After $48 \mathrm{~h}$, Serratia $\mathrm{spp}$. S2 still had the ability to reduce chromium as the $\mathrm{Cr}(\mathrm{VI})$ content continued to decrease. With regard to the ChrT-engineered bacteria, the capability to eliminate $\mathrm{Cr}(\mathrm{VI})$ was weaker than Serratia spp. S2, and the $\mathrm{Cr}$ (VI) concentration was higher than Serratia spp. S2 at 4, 8, 12, 24 and $72 \mathrm{~h}$. Furthermore, the $\mathrm{Cr}$ (VI) content was significantly lower in engineered bacteria than in the host E. coli BL21 (DE3). After $48 \mathrm{~h}$, the $\mathrm{Cr}$ (VI) concentration did not change with time in the engineered bacteria group, indicating that the capability had reached a maximum. Additionally, the host E. coli BL21 (DE3) was not capable of eliminating $\mathrm{Cr}$ (VI). Compared with the blank control, no significant difference was observed at the different time points. After $24 \mathrm{~h}$, the $\mathrm{Cr}$ (VI) concentration was $10 \%$ lower than it was at $0 \mathrm{~h}$, which may have been caused by a reducing substance in the medium that induced self-consumption of $\mathrm{Cr}$ (VI). The results indicated that ChrT-engineered bacteria had the capability to reduce $\mathrm{Cr}(\mathrm{VI})$. 
Table I. Detection of the activity of ChrT in engineering bacteria.

\begin{tabular}{lccr}
\hline Groups & $\mathrm{N}$ & $\mathrm{Cr}(\mathrm{VI})$ concentration $(\mu \mathrm{g})$ & ChrT activity $(\mathrm{U} / \mathrm{mg})$ \\
\hline Experimental group 1 (without NADPH) & 5 & $1.70 \pm 0.06$ & $6.92 \pm 0.53$ \\
Experimental group 2 (with NADPH) & 5 & $0.78 \pm 0.05$ & $14.83 \pm 0.39$ \\
Control & 5 & $2.49 \pm 0.04$ & - \\
$\chi^{2}$ & & 936.20 & $\mathrm{P}<0.01^{\mathrm{a}}$ \\
P-value & & & \\
\hline
\end{tabular}

${ }^{\mathrm{a}}<0.01$, control vs. experimental groups. $\mathrm{NADPH}$, nicotinamide adenine dinucleotide phosphate.

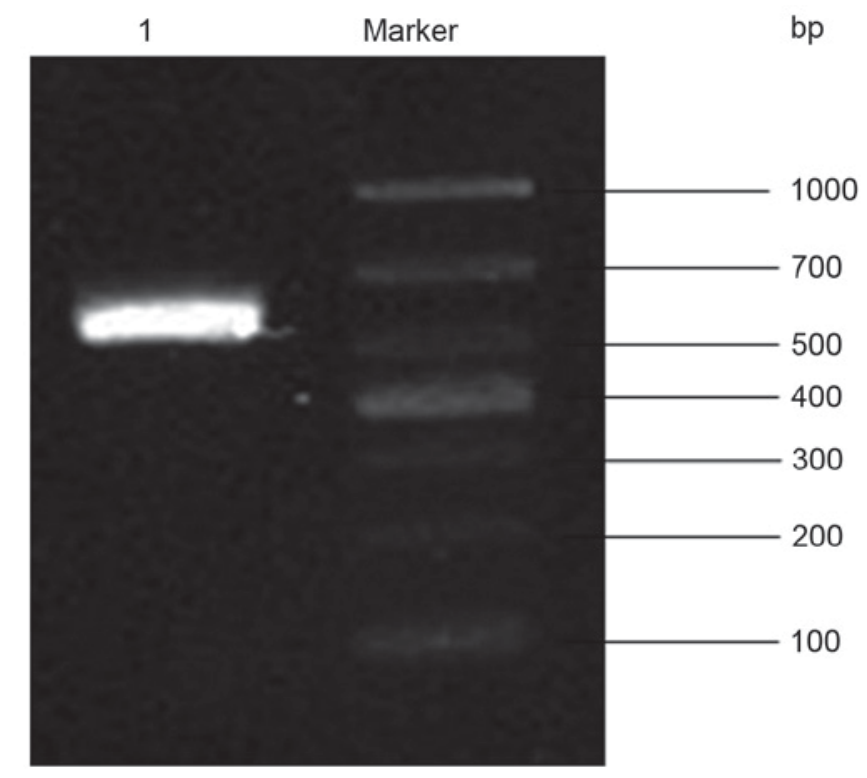

Figure 1. Identification of ChrT gene by polymerase chain reaction. Lane 1, amplification products.

Effects on Cr (VI) elimination capability by the culturing condition of ChrT-engineered bacteria. In order to estimate the influence of culturing conditions for ChrT-engineered bacteria (including $\mathrm{pH}$, temperature, carbon source and metal ion) on the reducing capability of $\mathrm{Cr}$ (VI), the $\mathrm{Cr}$ (VI) concentration was detected under different culturing conditions. As Fig. 3A shows, the capability to reduce $\mathrm{Cr}$ (VI) was the highest at $\mathrm{pH}$ 7.0 among pH 5.0-11.0. The remaining Cr (VI) was $20 \mathrm{mg} / \mathrm{l}$, which was significantly lower than that of the other groups $(\mathrm{P}<0.05)$. In an alkaline environment, the capability was the weakest. Therefore $\mathrm{pH} 7.0$ was determined to be the optimal $\mathrm{pH}$ for ChrT-engineered bacteria to reduce $\mathrm{Cr}(\mathrm{VI})$.

The $\mathrm{Cr}$ (VI) concentration in the medium at different culture temperatures $\left(20,25,30,37,40\right.$ and $\left.50^{\circ} \mathrm{C}\right)$ was also detected. As shown in Fig. 3B, the $\mathrm{Cr}$ (VI) concentration was reduced from $50 \mathrm{mg} / 1$ to $35.8,31.2,26.6,19.6,22.4$ and $36.1 \mathrm{mg} / \mathrm{l}$ at $20,25,30,37,40$ and $50^{\circ} \mathrm{C}$, respectively. The optimal temperature was $37^{\circ} \mathrm{C}$ for culturing ChrT-engineered bacteria, which significantly differed from the other temperatures $(\mathrm{P}<0.05)$.

In the $50 \mathrm{mg} / \mathrm{l} \mathrm{Cr}$ (VI) LB liquid medium, different carbon sources were added to the engineered bacteria to detect the $\mathrm{Cr}$ (VI) concentration. As shown in Fig. 3C, the Cr (VI) content

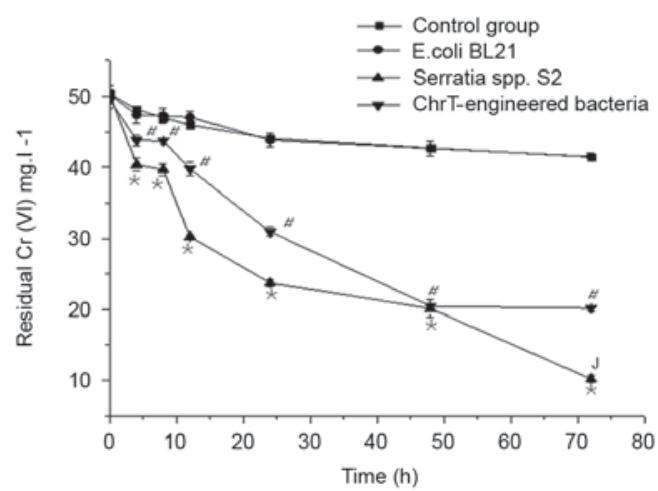

Figure 2. Comparison of $\mathrm{Cr}(\mathrm{VI})$ reduction ability among different strains. ${ }^{*} \mathrm{P}<0.05$ vs. other groups; ${ }^{\#} \mathrm{P}<0.05$ vs. E. coli $\mathrm{BL} 2$.

was significantly lower than the other groups when the medium was supplemented with and sodium acetate $(\mathrm{P}<0.05)$. The $\mathrm{Cr}$ (VI) reduction capability was the greatest in ChrT-engineered bacteria, in which the rate of $\mathrm{Cr}$ (VI) elimination increased by $\sim 25 \%$. In fact, sodium lactate, sodium citrate, sucrose, ethanol and glucose also exhibited a weak potential for reducing $\mathrm{Cr}$ (VI), whereas starch and methanol had no effect.

The effects of different metal ions on the capability of reducing $\mathrm{Cr}$ (VI) were also investigated. In the $\mathrm{LB}$ medium containing $50 \mathrm{mg} / \mathrm{l} \mathrm{Cr}(\mathrm{VI}), \mathrm{Ca}^{2+}, \mathrm{K}^{+}, \mathrm{Co}^{2+}, \mathrm{Mn}^{2+}, \mathrm{Zn}^{+}, \mathrm{Mg}^{2+}$, $\mathrm{Cu}^{2+}, \mathrm{Fe}^{3+}$ and $\mathrm{Pb}^{2+}$ were added into the medium. As shown in Fig. 3D, the majority of the ions had no significant effects on $\mathrm{Cr}$ (VI) reduction capability besides $\mathrm{Cu}^{2+}, \mathrm{Co}^{2+}$ and $\mathrm{Pb}^{2+}$ that significantly promoted the elimination capability of $\mathrm{Cr}$ (VI) $(\mathrm{P}<0.05)$. Amongst them, $\mathrm{Cu}^{2+}$ was the most effective at promoting the capability, as its associated $\mathrm{Cr}(\mathrm{VI})$ concentration was significantly lower than that of the other groups $(\mathrm{P}<0.05)$. Furthermore, the rate of $\mathrm{Cr}(\mathrm{VI})$ elimination was increased by $\sim 75 \%$. It was shown that $\mathrm{Mn}^{2+}$ is able to significantly repress the reduction capability compared with the control group $(\mathrm{P}<0.05)$ by decreasing the rate of $\mathrm{Cr}$ (VI) elimination by $\sim 50 \%$.

Expression positioning and activity of chrT. Electrophoresis was performed to identify the molecular weight of ChrT. Following IPTG induction, proteins from the periplasm, soluble intracellular components and inclusion bodies were extracted and separated by $15 \%$ SDS-PAGE. The molecular weight of known ChrT was $26 \mathrm{kDa}$. As shown in Fig. 4, small amounts of ChrT were expressed in the inclusion bodies and outer peripheral portion, while larger amounts of ChrT protein were expressed 
A

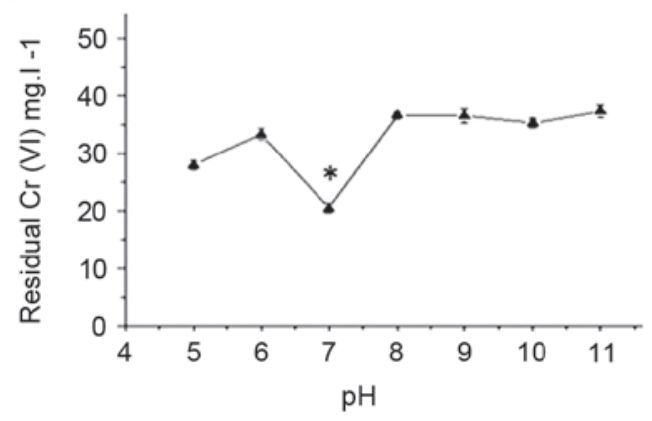

$\mathrm{C}$

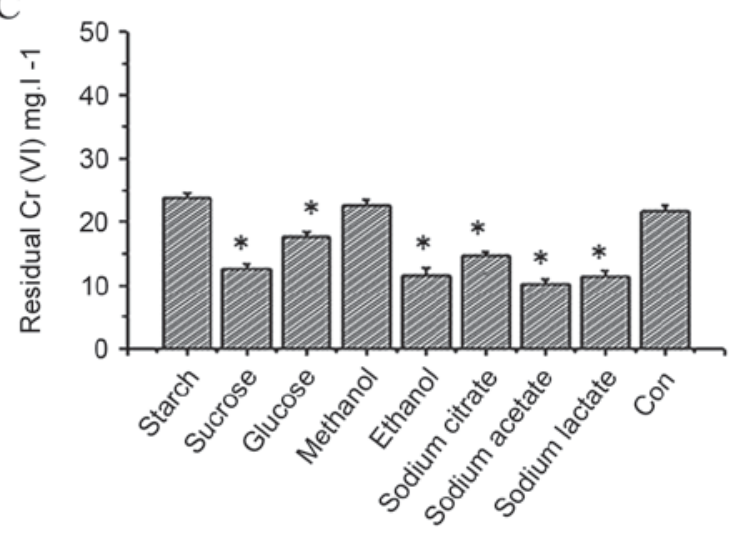

B

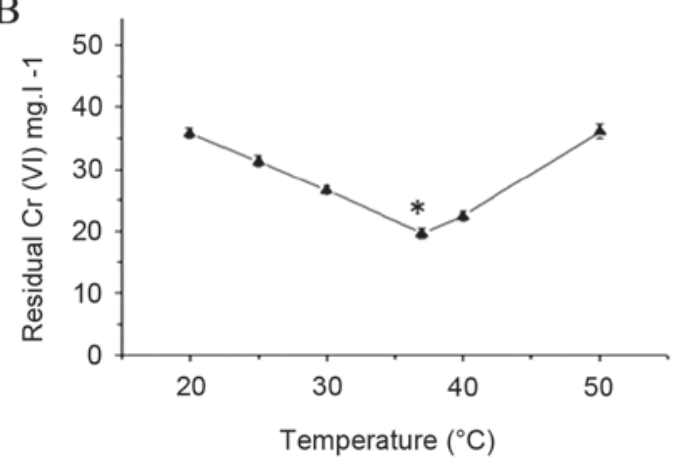

D

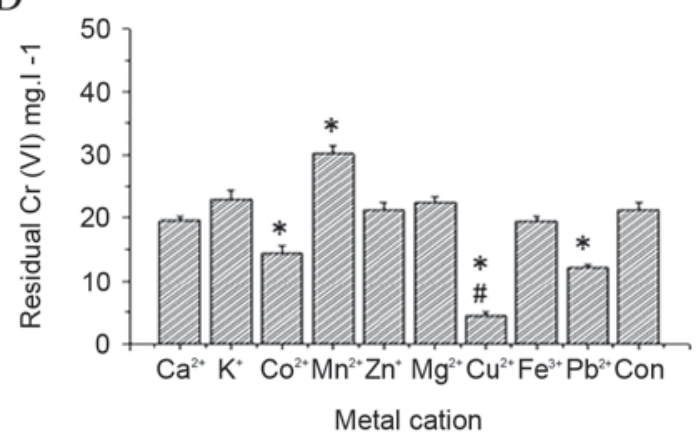

Carbon source

Figure 3. Influence of culture conditions for ChrT engineering bacteria on the reducing capability of $\mathrm{Cr}$ (VI). (A) Influence of pH on the reducing capability of $\mathrm{Cr}(\mathrm{VI})$ in $\mathrm{ChrT}$ engineered bacteria. ${ }^{*} \mathrm{P}<0.05$ vs. all other $\mathrm{pH}$ values. (B) Influence of temperature on the reducing capability of $\mathrm{Cr}(\mathrm{VI})$ in $\mathrm{ChrT}$ engineered bacteria. " $\mathrm{P}<0.05$ vs. all other temperatures. (C) Influence of carbon source on the reducing capability of $\mathrm{Cr}(\mathrm{VI})$ in $\mathrm{ChrT}$ engineered bacteria. ${ }^{*} \mathrm{P}<0.05$ vs. Con. (D) Influence of metal ions on the reducing capability of $\mathrm{Cr}(\mathrm{VI})$ in $\mathrm{ChrT}$ engineered bacteria. ${ }^{*} \mathrm{P}<0.05$ vs. Con; ${ }^{~} \mathrm{P}<0.05$ vs. all other cations. Con, control.

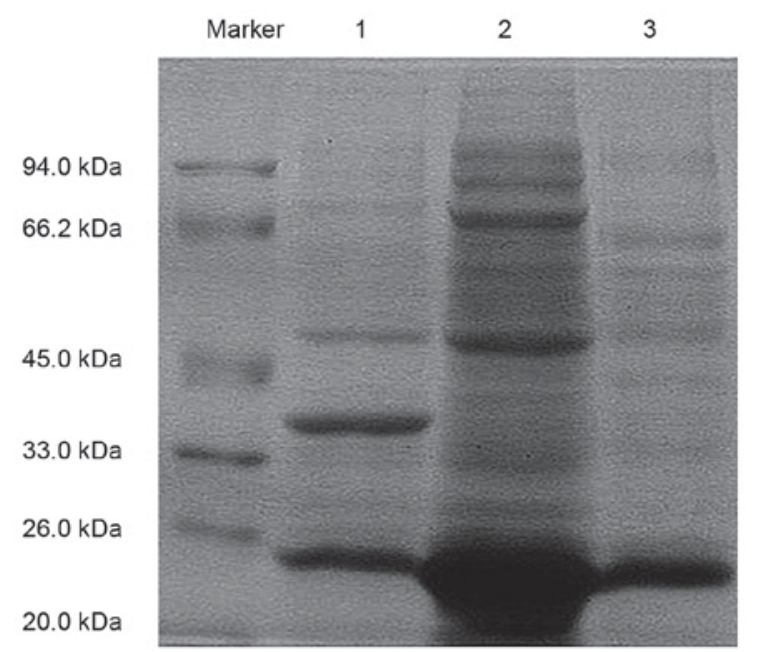

Figure 4. Investigating the ChrT expression position in bacteria via SDS-PAGE. Lane 1, outer peripheral; lane 2, intracellular; lane 3, inclusion body components.

in the soluble intracellular components. The results indicated that the soluble chromium reductase ChrT was the main form expressed.

To analyze the activity of ChrT in engineered bacteria, the supernatant was used to perform enzymatic reactions following sonication and centrifugation. As shown in Table I, the $\mathrm{Cr}$ (VI) concentration was significantly lower in the two experimental groups when compared with the control group, which indicated that the extracted ChrT had the capability to reduce $\mathrm{Cr}(\mathrm{VI})$. In the second experimental group, the activity of ChrT was significantly increased when NADPH was used as the electron donor $(\mathrm{P}<0.05)$. Furthermore, the reduction of $\mathrm{Cr}$ (VI) was improved, and the enzymatic activity was increased from $6.92 \pm 0.53$ to $14.83 \pm 0.39 \mathrm{U} / \mathrm{mg}$. Compared with the group without NADPH, the enzymatic activity was increased by $\sim 114 \%$. These results indicated that NADPH was able to promote the reductase capability of ChrT.

\section{Discussion}

Using genetic engineering technology, ChrT-engineered bacteria were constructed based on E. coli BL21 (DE3) that were transformed into a pET-28a (+) vector that contained the ChrT gene (14). The sequence of ChrT was amplified from Serratia spp. S2 genomic DNA and cloned into the pET-28a (+) vector (14). In the present study, the ChrT-engineered bacteria were capable of eliminating $\mathrm{Cr}$ (VI), which was a little weaker than wild type Serratia sp. S2 bacteria. This may have been due to more than one gene associating with $\mathrm{Cr}$ (VI) reductase in the selected wild-type strain. Furthermore, it has been shown that the chromium resistance, chromium transfer-associated and nitrate or nitrite reductase genes were associated with the capability of 
chromium reduction (18). The present study only attempted to induce one gene associated with chromium reduction, which limits the capability of reducing $\mathrm{Cr}$ (VI). However, in future studies, multiple related genes should be imported into the host genome.

The optimal reaction system of ChrT-engineered bacteria demonstrated that the capability of eliminating $\mathrm{Cr}$ (VI) was the strongest at $37^{\circ} \mathrm{C}$ and $\mathrm{pH} 7.0$, which may be correlated with the type of the host bacteria. Additionally, the optimum temperature and $\mathrm{pH}$ for the host E. coli $\mathrm{BL} 21$ (DE3) is $37^{\circ} \mathrm{C}$ and $\mathrm{pH}$ 7.2-7.4 (19). Inappropriate environmental conditions influence the growth of host bacteria, which may affect the capability of eliminating $\mathrm{Cr}$ (VI). The host bacteria with a broad adaptability to the environment can be selected for future studies. In biodegradation, the main problems to be solved are the effects of other pollutants on reducing $\mathrm{Cr}$ (VI), in which the most common is the interference of metal ions (20). In the present study, it was shown that the majority of common metal ions did not inhibit the $\mathrm{Cr}$ (VI) reduction in engineered bacteria, whereas $\mathrm{Cu}^{2+}, \mathrm{Co}^{2+}$ and $\mathrm{Pb}^{2+}$ promoted the elimination capability, which was beneficial to the real application in the environment. Furthermore, the carbon source is not just a necessary energy substance but it is also used as the electron donor. One advantage in biological treatment of heavy metal pollution is the inexpensive electron donor, and $\mathrm{Cr}$ (VI) can be reduced continuously under enough electron donors (21). Therefore, it is important to study the effects of carbon sources.

The ChrT belongs to the FMN_red enzyme family (22). Additionally, the mainmechanism of $\mathrm{Cr}(\mathrm{VI})$ is electron transfer from $\mathrm{NAD}(\mathrm{P}) \mathrm{H}$ to $\mathrm{Cr}(\mathrm{VI})$, a coenzyme, that is reduced to $\mathrm{Cr}$ (III) (23). It was demonstrated that adding NADPH improved the capability of eliminating $\mathrm{Cr}$ (VI) by ChrT and ChrT is induced by IPTG. The majority of the recombinant proteins expressed in the prokaryotic expression system were formed in inclusion bodies, which have no biological activity although the amino acid sequence is correct. Furthermore, the processes of renaturation are complex, time consuming and with a low success rate. Through position and activity analysis, it was validated that the majority of ChrT was soluble and was found in the cytoplasm of the host bacteria. In further studies, ChrT could be purified using GST affinity chromatography from the supernatant by ultrasound (24), which is particularly valuable to the practical application.

ChrT gene was cloned from Serratia spp. S2 bacteria that have a high resistance to chromium although Serratia spp. S2 bacteria could easily lead to biological contamination due to its high pathogenesis. Furthermore, the bacteria constructed by genetic engineering technology had a limited capability of eliminating $\mathrm{Cr}$ (VI), but this can be improved by changing the physical and chemical environment. The host bacteria belonged to $E$. coli, so the level of biosafety was high. Furthermore, the constructed bacteria can be used to extract large amounts of chromium reductase, which can be used directly to eliminate chromium.

In the present study, ChrT-engineered bacteria and induced chromium reductase were shown to be capable of reducing $\mathrm{Cr}$ (VI), which provided the basis and developmental value to the practical application of engineered bacteria and ChrT in $\mathrm{Cr}$ (VI) polluted soil and water.

\section{Acknowledgements}

The present study was supported by the Scientific and Technological Research projects of the Chongqing City Board of Education (grant no. KJ1500216), Students Scientific Research and Innovation Project of Chongqing Medical University (grant no. 201410), the Fundamental and Advanced Research Foundation of Chongqing Science and Technology Commission (grant no. cstc2013jcyjA20004) and the National Natural Science Foundation of China (grant no. 21403021).

\section{References}

1. Xiao W, Wang L, Li ZK, Zhang SW and Ren DM: Mechanisms and enzymatic characters of hexavalent chromium reduction by Bacillus cereus S5.4. Huan Jing Ke Xue 29: 751-755, 2008 (In Chinese).

2. Messer J, Reynolds M, Stoddard L and Zhitkovich A: Causes of DNA single-strand breaks during reduction of chromate by glutathione in vitro and in cells. Free Radic Biol Med 40: 1981-1992, 2006.

3. Cheung KH and Gu JD: Mechanism of hexavalent chromium detoxification by microorganisms and bioremediation application potential: A review. Int Biodeterioration Biodegradation 59: 8-15, 2007.

4. Huang S: Study on the isolation and identification of Pannonibacter phragmitetus $\mathrm{BB}$ and its reducing $\mathrm{Cr}(\mathrm{VI})$. Hunan You Se Jin Shu 26: 52-57, 2010 (In Chinese).

5. Dönmez G and Koçberber N: Bioaccumulation of hexavalent chromium by enriched microbial cultures obtained from molasses and $\mathrm{NaCl}$ containing media. Pro Biochem 40: 2493-2498, 2005.

6. Yang W, Wang J, Mu Q, Zhen J and Chen G: Screening of Cr (VI)-resistant strains and condition optimization. Henan Science 8: 1175-1179, 2013.

7. Elangovan R, Philip L and Chandraraj K: Hexavalent chromium reduction by free and immobilized cell-free extract of Arthrobacter rhombi-RE. Appl Biochem Biotechnol 160: 81-97, 2010.

8. Zhao C, Yang Q, Chen W and Teng B: Removal of hexavalent chromium in tannery wastewater by Bacillus cereus. Can J Microbiol 58: 23-28, 2012

9. Soni S, Singh R, Awasthi A and Kalra A: A Cr(VI)-reducing Microbacterium sp. strain SUCR 140 enhances growth and yield of Zea mays in $\mathrm{Cr}(\mathrm{VI})$ amended soil through reduced chromium toxicity and improves colonization of arbuscular mycorrhizal fungi. Environ Sci Pollut Res Int 21: 1971-1979, 2014.

10. Thacker U, Parikh R, Shouche Y and Madamwar D: Reduction of chromate by cell-free extract of Brucella sp. isolated from $\mathrm{Cr}(\mathrm{VI})$ contaminated sites. Bioresour Technol 98: 1541-1547, 2007.

11. He D, Zheng M, Ma T, Li C and Ni J: Interaction of Cr(VI) reduction and denitrification by strain Pseudomonas aeruginosa PCN-2 under aerobic conditions. Bioresour Technol 185: 346-352, 2015.

12. Thatoi H, Das S, Mishra J, Rath BP and Das N: Bacteria chromate reductase, a potential enzyme for bioremediation of hexavalent chromium: A review. J Environ Manage 146: 383-399, 2014.

13. Liu X, Wu G, Zhang Y, Wu D, Li X and Liu P: Chromate Reductase YieF from Escherichia coli enhances hexavalent chromium resistance of human HepG2 Cells. Int J Mol Sci 16: 11892-11902, 2015.

14. Deng P, Tan X, Wu Y, Bai Q, Jia Y and Xiao H: Cloning and sequence analysis demonstrate the chromate reduction ability of a novel chromate reductase gene from Serratia sp. Exp Ther Med 9: 795-800, 2015.

15. Tan X, Deng P, Wu Y, Bai Q, Jia Y and Xiao H: In vitro synthesis and activity identification of Chromate reductase T. Chongqing Yike Daxue Xuebao 39: 973-977, 2014 (In Chinese).

16. Tan X: Cloning, expression and activity of ChrT gene from Serratia sp. CQMUS2: Chongqing Medical University, 2014 (In Chinese).

17. GB/T 7467-1987: Water quality-Determination of chromium (VI)-Diphenylcarbahydrazide spectrophotometric method. China Standards Press, Beijing, 1987 (In Chinese).

18. He M: Chromium reduction and whole genome sequence analysis of high efficient chromium reduction bacteria Bacillus cereus SJ1 and Lysinibacillus fusiformis ZC1: Huazhong Agricultural University; 2010 (In Chinese). 
19. Fan ZH, Liang P, Fan XH, Zhang AL and Chen YJ: Study on the effects of incubating conditions on E. coli accumulating L asparaginase. Shi Pin Gong Ye Ke Ji 30: 167-169, 2009 (In Chinese).

20. Chovanec P, Sparacino-Watkins C, Zhang N, Basu P and Stolz JF: Microbial reduction of chromate in the presence of nitrate by three nitrate respiring organisms. Front Microbiol 3: 416, 2012.

21. Xiao W, Wang L, Zhang S, Qiao W, Fu X and Ren D: Screening, identification and reduction characteristic of hexavalent chromium-reducing bacteria Bacillus cereus S5.4. Industrial Microbiol 37: 1-6, 2007.
22. Tan XQ, Bai QH, Han LL, Cao XQ and Xiao H: Cloning and sequence analysis of FMN_red gene fragment from Serratia sp. CQMUS2. Biotechnology 5: 002, 2013.

23. Ramírez-Díaz MI, Díaz-Pérez C, Vargas E, Riveros-Rosas H, Campos-García J and Cervantes C: Mechanisms of bacterial resistance to chromium compounds. Biometals 21: 321-332, 2008.

24. Jiang J, Zheng Y, Jiang $H$ and Yang G: Highly efficient soluble expression, purification and activity of SEB superantigen antagonist in E. coli. Qiannan Min Zu Shi Fan Xue Yuan Xue Bao 32: 103-107, 2012 (In Chinese). 